\title{
Devlet Bütçesi Açısından Adalet Hizmetleri ve Harcamaları: Türkiye Üzerine Bir Değerlendirme
}

\begin{abstract}
Haluk Egeli ${ }^{1}$
Ayşe Atılgan Yaşa ${ }^{2}$

Devlet Bütçesi Açısından Adalet Hizmetleri ve Harcamaları: Türkiye Üzerine Bir Değerlendirme

Öz

Toplumun ortak ihtiyaçlarına yönelik sunulan bir kamu hizmeti olarak adalet hizmetleri, devlet bütçesinden ayrılan paylar açısından adalet harcamalarını oluşturmaktadır. Türkiye'de adalet hizmetlerine yönelik yapılan harcamalar ile adalet hizmetlerinden beklenen etkinliğe ulaşılabilmesi, devlet bütçesinden ayrılan pay ile doğrudan ilişkilidir. Bu kapsamda çalışmada öncelikle adalet ve adalet hizmetleri kavramsal boyutları yönüyle ele alınmıştır. Daha sonra adalet hizmetlerinin özellikleri ve ekonomi üzerindeki etkilerine yer verilmiş olup adalet harcamalarının merkezi yönetim bütçesindeki yeri ve gelişimi değerlendirilmiştir.

Justice Services and Expenditure in terms of Government Budget: An Assesment of Turkey

Abstract

Justice services as a public service offered for the common needs of the society constitute the expenditures of justice in terms of the shares which separated from the government budget. The expenditures made for justice services in Turkey and the efficiency expected from justice services are directly related to the share allocated from the government budget. In this context, firstly the conceptual dimensions of justice and justice services are taken into consideration. Later, the characteristics of justice services and their effects on the economy were mentioned and the place and development of justice expenditures in the central government budget were evaluated.
\end{abstract}

Anahtar Kelimeler: Adalet Hizmetleri, Adalet Harcamaları, Devlet Bütçesi.

Keywords: Justice Services, Justice Expenditure, Government Budget.

\section{Giriş}

Adalet, insanların topluluklar halinde yaşamaya başladığı andan itibaren günümüze kadar önemsenen temel değerler arasında yer almaktadır. Devletin kurum olarak ortaya çıkmasıyla adalet kavramı geliştirilmiş ve devletin temel hizmetleri arasında yerini almıştır.

Adalet bir tam kamusal maldır. Bu nedenle arzı siyasal süreç ile belirlenir, faydası bölünemez, zorunlu tüketim malıdır ve büyük ölçekte üretilir. Kamusal malların hizmete dönüşmesi harcamalar yoluyla gerçekleşmektedir. Dolayısıyla adalet hizmeti de adalet harcamaları yapılarak devlet tarafından gerçekleştirilir. Adalet hizmetinin bir kamu harcaması olması, hem ülke ekonomisi üzerindeki etkileri hem de devlet bütçesindeki yeri boyutuyla incelenmesi gereken bir alan niteliği taşımaktadır.

Bu çalışma, temel kamu hizmetlerinden biri olan adalet hizmetleri ve harcamalarını merkezi yönetim bütçesindeki nispi önemi ve payları yönünden ele almaktadır. Bu bağlamda, öncelikle adalet ve adalet hizmetleri kavramsal boyutları itibariyle incelenmiş, daha sonra adalet harcamalarının merkezi yönetim bütçesindeki payları yıllar itibariyle değerlendirilip bazı tespit ve yorumlara yer verilmiştir.

\footnotetext{
${ }^{1}$ Prof. Dr., Dokuz Eylül Üniversitesi, İiBF, Maliye Bölümü, haluk.egeli@deu.edu.tr

${ }^{2}$ Araş. Gör. Dr., Dokuz Eylül Üniversitesi, iiBF, Maliye Bölümü, ayse.atilgan@deu.edu.tr
} 


\section{Kavramsal Boyutuyla Adalet ve Adalet Hizmetleri}

\subsection{Adalet}

Adalet kavramı, genel bir ifade ile "hakkı olana hakkının, ceza alması gerekene ise cezasının mahkemeler aracılığıyla verilmesi" olarak tanımlanabilmektedir.

Tarih boyunca "adalet" kavramına farklı anlamlar yüklenmiştir. Örneğin, pozitivist teoriye göre adalet, fiziki, olgusal bir gerçeklik değil, bir "değer"dir ve bir değer olarak fiziki âlemde değil, fizik ötesi âlemde yer almaktadır (Gözler, 2008: 86). Adalet kavramı, bünyesinde iyilik gibi mutlak bir değer taşıması nedeniyle erdemler hiyerarşisinde yüksek bir konumda bulunmasına rağmen, içinde barındırdığı duygu ve inanç unsurları yüzünden açıklıkla tanımlanamamaktadır (Sili, 2014: 376).

Adalet kavramının hukuki açından tanımlamaları yapılmıştır. Örneğin, Aristotales'e göre adalet, hukuki ilişkide taraf olanların eşit muamele görmesini gerektirmektedir. Hobbes 'sözleşmeye uymamayı adaletsizlik' olarak nitelendirmiştir. Kant ise, adalet kavramını ele alırken üç temel noktaya dikkat çekmektedir. Bunlar; 'şerefi yaşa', 'kimseye zarar verme', 'herkese payına düşeni ver' ilkeleri olmuştur (Güriz, 2001: 14).

Adalet kavramının hukuki ve felsefi boyutlarının yanında, bir de kamu hizmeti boyutu bulunmaktadır. Devletin temel görevleri arasında yer alan adalet kavramı devletin var oluşu ile somutlaşmıştır (Güriz, 2001: 13). Gerçek ve tüzel tüm kişilerin hak ehliyetine sahip olmaları ve sahip olunan hakların çeşitli şekillerde ihlal edilebilme ihtimalinin her zaman bulunması dolayısıyla adalet hizmeti toplumdaki tüm bireyleri, kurum ve kuruluşları yakından ilgilendirmektedir (Balcı, 2010: 24).

\subsection{Adalet Hizmetleri}

Kamu hizmetleri, toplumun ortak ihtiyaçlarını karşılama amaçlı, devlet tarafından topluma sunulan hizmetler olarak nitelendirilmektedir. Devletin adalet, eğitim, sağ|ık, güvenlik gibi görevleri yerine getirebilmesi için harcama yapması gerekmektedir. Söz konusu harcamalar hizmetlerin somutlaştırılmış hali olup kamusal hizmetlerin parasal yönü kamu harcaması olarak ifade edilmektedir (Eker, 2009: 129).

Kamusal mal ve hizmetler toplumun tümü için üretilir, herhangi bir kişi veya toplumun bir kesimi bu tür mal ve hizmetlerin faydasından mahrum bırakılmak istendiğinde toplumun tamamı söz konusu mal ve hizmetlerin faydasından mahrum bırakılmış olur (Methibay, 2014: 11).

Adalet hizmetleri, devletin temel hizmetlerinden biridir. Kamu hizmetlerinin bölünemez niteliğinden ötürü, kişilerin ihtiyaçlarına göre miktarı ayarlanamamaktadır. Bu yönden ortak tüketim mallarında yararlananların tümü için üretim miktarı sabittir. Çünkü kamu hizmetleri, kişilere sunulacak hizmetin miktar ve niteliğini belirleme olanağı tanımamaktadır (Bulutoğlu, 2008: 29).

Adalet hizmetleri, belirli kesimleri etkileyen bir özelliğe sahiptir. Bu çerçevede adalet olgusunu meydana getiren kurallar ve düzeni belirleyen kanunlar, kanunları uygulayan kamu görevli ve taraflar arasında ortaya çıkan uyuşmazlıkların çözümünde adalet sistemini kullanan kişi ve kurumlardır. Bu kesimler, davalı ve davacı taraflara sunulan hizmetlerden yararlanmaktadır. Buna göre, adalet hizmetleri, devletin adalet işini yürütebilmesi için davacı ve davalı taraflara mahkemeler ve diğer kurumlar ile hizmetin sunumunda aktif rol oynayan birimlerin sunduğu hizmetler olarak da ifade edilebilmektedir. Adalet hizmetinin yürütülmesi için yapılan harcamalar da fonksiyonel olarak adalet harcamalarını oluşturmaktadır. 
Adalet hizmetinin etkin bir şekilde gerçekleştirilebilmesi ve sonuçlarının yararlı olabilmesi için yargılama işlevinin sağlıklı bir şekilde yürütülmesi gerekmektedir. Suçların cezalandırılması ve ihtilafların hukuka uygun olarak çözümü aşamalarından oluşan yargılama işlevi, yasa ve düzen egemenliğinin devlet gücüne dayanan yaptırımlarıdır (Bulutoğlu, 2008: 232).

\subsubsection{Adalet Hizmetlerinin Özellikleri}

Ekonomik açıdan mallar, özel mallar ve kamusal mallar olarak ikiye ayrılmaktadır. Özel tüketime konu olan mallar farklı bireylerin tükettiği malların toplamından oluşmaktadır ve bir piyasa ekonomisinde, piyasa işleyişi içinde özel üretim birimleri tarafından sunulmaktadır (Kirmanoğlu, 2014: 123). Kamusal mallarda ise durum daha farklıdır ve bir bireyin tüketimi diğer bireyin tüketimini azaltmamaktadır dolayısıyla kamusal mallar bölünemez mal olarak tanımlanmaktadır (Aktan, 2013: 9-10).

Adalet hizmetlerinin de toplumun tümüne sunulması bu kamusal malın bölünemez mal niteliğini taşımasını sağlamaktadır. Esasen adalet hizmetleri tam kamusal mal ve hizmetler kategorisinde yer almasına rağmen fayda ölçütüne göre tüm topluma faydalı olmakla birlikte bazı kişilere özel menfaat sağlayan hizmetler grubuna dâhil edilmektedir. Bu hizmetlerden bazı kişiler hiç yararlanmadıkları halde bazıları da sürekli yararlanabilmektedir. Ancak bir kişinin adalet hizmetinden özel menfaat sağlaması adalet hizmetinin sosyal fayda yönünden tam kamusal mal ve hizmet olma özelliğini ortadan kaldırmamaktadır. Çünkü adalet hizmetleri tüm toplumun geneline yayılma özelliğine sahiptir.

Adalet hizmetlerinin genel olarak özellikleri aşağıda yer alan Şekil 1'de yer aldığı gibi özetlenebilmektedir:

Şekil 1: Adalet Hizmetlerinin Özellikleri

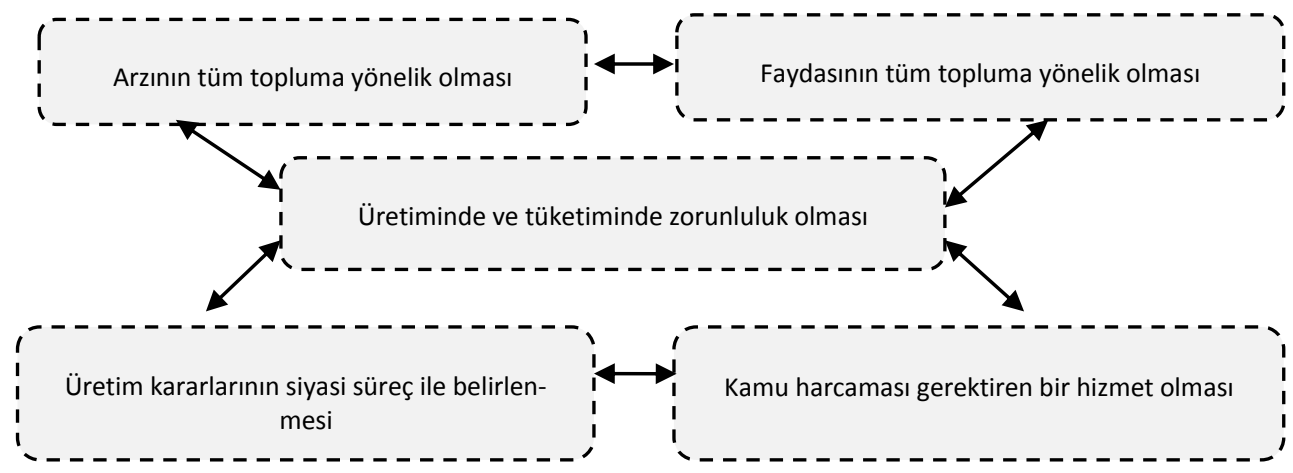

2.2.2. Adalet Hizmetlerinin Ekonomik Etkileri

Toplumsal gelişme sürecinde, sosyal ve ekonomik ilişkilerin artması, bireyler ve kurumlar arası ilişkide ve bunların birbirleriyle olan ilişkilerinde anlaşmazlıkların artmasına neden olmaktadır. Anlaşmazlıklara yönelik çeşitli çözüm yolları bulunmakla birlikte, birçok anlaşmazlığın çözüm yolunun adli makamlar olması, günümüzde adalet hizmetlerine olan talebi de arttırmaktadır.

Adalet sisteminin iyileştirilmesi neticesinde oluşan hukukun üstünlüğü ile bireylerin ekonomik faaliyetlerini yapılandırmaları ve anlaşmazlıkları çözmek için yasal sistemi kullanmaları gerekmektedir (Hay ve diğerleri, 1996: 559). Bireyler yasal kuralların ne olduğunu öğrendiğinde, bu kuralları kullanarak ekonomik işlemlerini yapılandırabilecekleri gibi kuralları ihlal edenler ise 
tazminat ödeyerek veya cezasını çekerek adalet sisteminin işleyişini sürdürebilmektedir. Mahkeme gibi kurumlar ve polis gibi kamu görevlileri tarafından bu kuralların uygulamaya konması da bireylerin ekonomik faaliyetleri sırasında adalet sistemi ile olan ilişkilerini düzenlemektedir (Pinheiro, 1996: 4).

Adalet ve etkinlik, adalet hizmetlerinin sunumunda belirlenmiş en önemli amaçlardır. Adalet sisteminin etkinliğini belirleyen faktörleri ise; mali yapı, personel yapısı, teşkilat yapısı, alt yapı ve teknoloji, yargılama usulleri, davaların görüşülme süresi, dosya başına düşen hâkim ve savcı sayısı, mahkemelerin bağımsız ve tarafsız olması gibi sıralamak mümkündür. Bu faktörlerin gerçekleştirilmesi, özellikle adalet hizmetlerinden beklenen verimliliğin artacağına anlamına gelmektedir.

Adalet hizmetleri; teknolojik gelişmeler, yatırımların artışını doğrudan belirleyen firma tercihleri gibi alanlarda ekonomiyi etkileyebilmektedir. Adalet hizmetlerinin adil ve etkin yürütülebilmesi için ülkelerin bu alana ayıracakları bütçe büyüklüklerine bağlı olarak ekonomik büyüme ve kalkınma hedefleri gerçekleşmektedir. Adalet harcamalarının ülke bütçelerinde genellikle düşük bir paya sahip olması nedeniyle adalet sisteminin ekonomik büyüme üzerine etkileri konusunda literatürde çok az sayıda çalışmaya yer verildiği görülmektedir (Pinheiro, 1996: 3).

Adalet sistemi, sermaye birikimi yoluyla da ekonomik büyümeyi olumlu yönde etkileyebilmektedir. Sermayelerini yatırıma dönüştürecek olan bireylerin mülkiyet haklarının korunması, adalet hizmetlerinin etkinliği ile doğrudan ilişkilidir. Aksi takdirde etkin olmayan bir adalet sistemi, finansal yatırımlara yönelecek fonların değerlerinde azalmaları beraberinde getirerek, tasarrufları ve sermaye hareketlerini olumsuz yönde etkileyebilmektedir. Sonuç olarak, adalet devlet bütçesinde bir harcama kalemi olması ve adalet hizmetinin sunumundan sonra alınan kararlar ile ekonomiyi etkilediği görülmektedir (Deyneli, 2011: 9).

Adalet sisteminde reform yapılması, gelişmekte olan ülkelerdeki ve geçiş ekonomilerindeki piyasa koşullarına adalet hizmetlerinin uygun hale getirilmesini ifade etmektedir (Messick, 1999: 118). Reformlar neticesinde mahkemelerin bağımsız olması da yatırımları ve ekonomik büyümeyi arttırıcı bir etkiye sahip olacaktır (Klerman, 2007: 434).

\section{3. Türkiye'de Adalet Harcamalarının Merkezi Yönetim Bütçesi Yönünden Değerlendiril- mesi}

Kamu harcamaları hukuki açıdan, kamu kurumlarının yaptığı harcamalardır. Hukuki tanımlar genel olarak mali kanunlarda yer almıştır. Ülkemizde bütçe uygulamalarına yön veren en önemli kanun olarak bilinen 5018 sayılı Kamu Mali Yönetimi ve Kontrol Kanunu madde 3'de kamu harcamaları, 'kamu gideri' olarak tanımlanmıştır. Söz konusu maddeye göre kamu gideri, "kanunlarına dayanılarak yaptırılan iş, alınan mal ve hizmet bedelleri, sosyal güvenlik katkı payları, iç ve dış borç faizleri, borçlanma genel giderleri, borçlanma araçlarının iskontolu satışından doğan farklar, ekonomik, malî ve sosyal transferler, verilen bağış ve yardımlar ile diğer giderler" $\mathrm{i}$ ifade etmektedir.

Ülkemizde 5018 sayılı Kanun'un alt yapısını oluşturmak açısından 2002 yılında pilot seviyede çalışmaları başlatılan analitik bütçe sınıflandırması (analitik bütçe kod yapısı), 2004 mali yılında genel ve katma bütçelerle uygulaması başlayan ve giderek kamu iktisadi teşebbüsleri dışında 2006 mali yılından itibaren kamu kuruluşlarının tümünü kapsayan bir uygulamaya dönüşmüştür (Tüğen, 2016: 213). Analitik bütçe sınıflandırmasına göre, adalet hizmetleri fonksiyonel sınıflandırmaya göre 03 kod ile 'Kamu Düzeni ve Güvenlik Hizmetleri' başlığı altında izlenmektedir. Fonksiyonel sınıflandırmada adalet harcamaları, 'Kamu Düzeni ve Güvenlik Hizmetleri' olarak 
görünse de, Adalet Bakanlığı bünyesinde adalet harcamaları, 'Genel Kamu Hizmetleri, Savunma Hizmetleri ve Kamu Düzeni ve Güvenlik Hizmetleri' olarak sınıflandırılmaktadır.

Türkiye'de adalet hizmetinin icrasından sorumlu temel kuruluşlar, Adalet Bakanlığı, Anayasa Mahkemesi, Yargıtay, Danıştay, Askeri Yargıtay, Askeri Yüksek İdare Mahkemesi Hâkimler ve Savcılar Yüksek Kurulu "dur. Bu kuruluşların harcamaları fonksiyonel açıdan adalet harcamaları olarak görülebilmektedir. Fakat Avrupa Konseyi'ne üye 47 ülkenin adalet sistemlerini değerlendirerek karşılaştırmalı bir çalışma yapmayı hedefleyen Avrupa Adaletin Etkinliği Komisyonu (CEPEJ)'in Türkiye için adalet harcamaları üzerine yapılan analizlerinde Adalet Bakanlığı bütçesi kullanılmıştır (Cepej, 2008: 19).

CEPEJ'in 2012 yılı verilerine dayalı olarak hazırladığı 2014 yılı Avrupa Yargı Sistemleri Raporuna göre; Avrupa Konseyi ülkelerinde yüz bin kişiye düşen hâkim sayısı, ortalama 21,3; savcı sayısı ise 11,1'dir. Ülkemizde ise 2015 yııının Mayıs ayı itibarıyla yüz bin kişiye düşen hâkim sayısı ortalama 13, savcı sayısı 6,5 dir (Adalet Bakanlığı Stratejik Planı, 2015-2019: 45). 2016 yılı sonu itibariyle yüz bin kişiye düşen hâkim sayısı ortalama 13,92, savcı sayısı 6,04 olarak belirlenmiştir. Adalet Bakanlığı'nın 2019 yılı stratejik plan hedefine göre, yüz bin kişi başına düşen hâkim sayısı ortalama olarak 21'e, savcı sayısı ise 11,8'e çıkartılması hedeflenmektedir (Adalet Bakanlığı Faaliyet Raporu, 2016: 68-201).

CEPEJ'e göre Adalet Bakanlığı'nın yıllık genel bütçesindeki bileşenlerin tanımları Şekil 2'de gösterilmiştir.

Şekil 2: Adalet Bakanlığı'nın Yıllık Genel Bütçesindeki Bileşenler

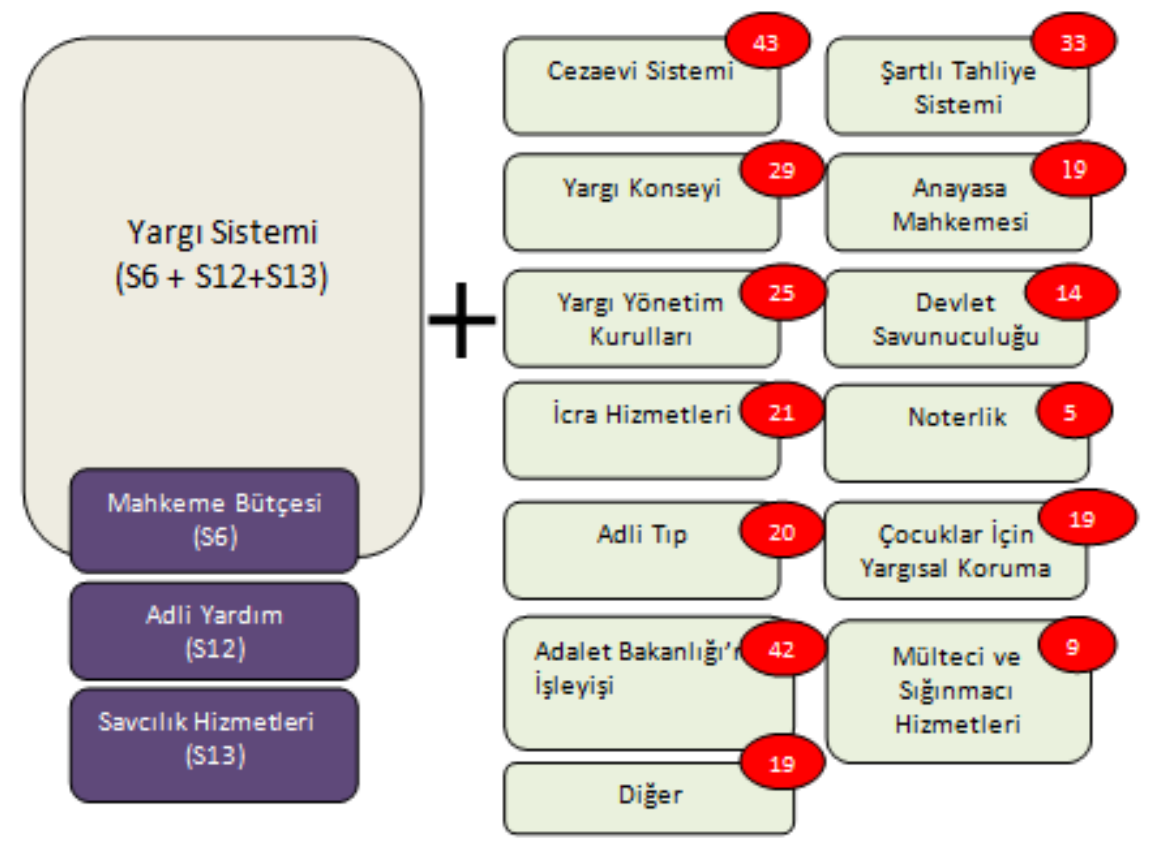


Eskişehir Osmangazi Üniversitesi iißBF Dergisi

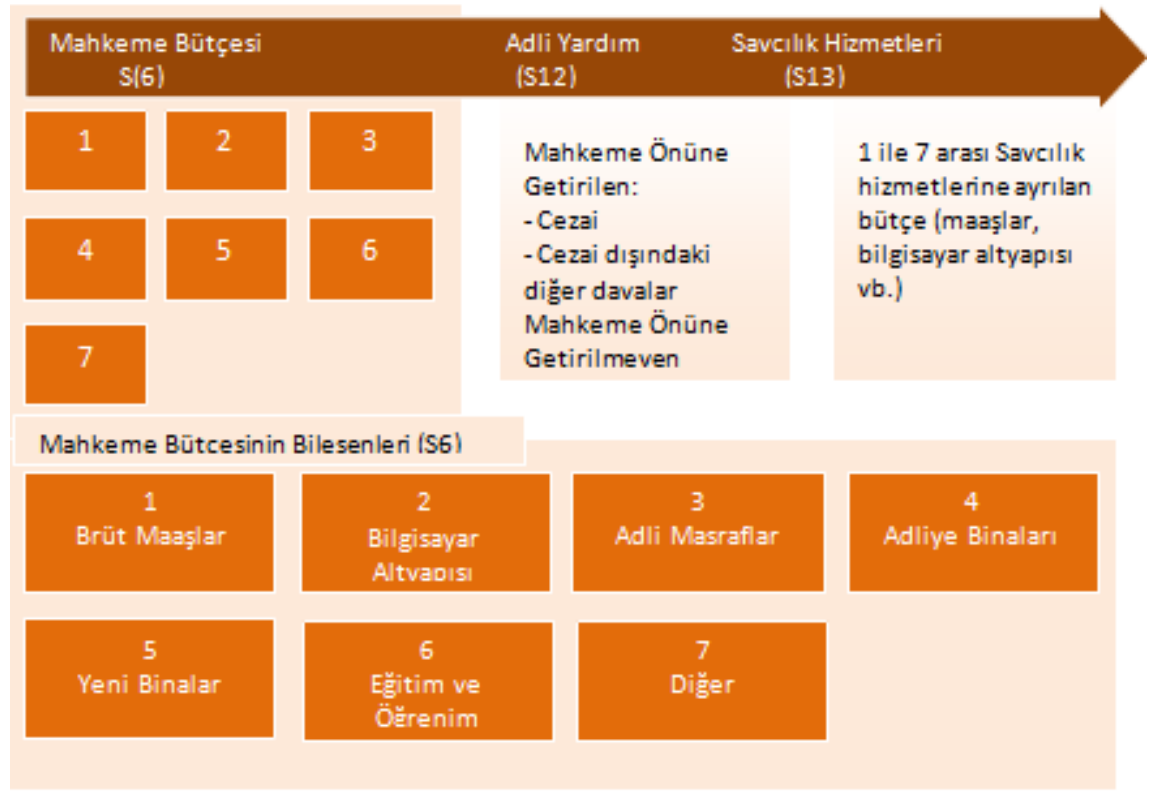

Kaynak: (CEPEJ, 2014: 27)

Şekil 2'ye göre CEPEJ, yargı sistemlerinin işleyişini ve mahkemelerin faaliyetlerini derinlemesine analiz edebilmek için tahsis edilen bütçeyi tanımlamayı ve yönlendirmeyi amaçlamaktadır. Bunun için CEPEJ'in raporlarında mahkemelerin, savcılık hizmetlerinin ve adli yardımın bütçelerine odaklanılmaktadır.

Aşağıda yer alan tabloda adalet harcamalarının gelişimi 2006-2016 dönemi için ele alınmıştır.

Tablo 1: 2006-2016 Yılları Arası Adalet Bakanlığı Ödeneklerinin, Merkezi Yönetim Bütçesi içindeki Payı (Milyon TL)

\begin{tabular}{ccccc}
\hline YIL & $\begin{array}{c}\text { Adalet Bakanlığı } \\
\text { Ödenekleri }\end{array}$ & $\begin{array}{c}\text { Merkezi Yönetim } \\
\text { Bütçesi Ödenekleri }\end{array}$ & $\begin{array}{c}\text { Adalet Bakanlı̆̆ı } \\
\text { Odeneklerinin Mer- } \\
\text { kezi Yönetim } \\
\text { Bütçesi İçindeki } \\
\text { Oranı \% }\end{array}$ & $\begin{array}{c}\text { Adalet Bakanlı̆̆ı } \\
\text { Ödeneklerinin } \\
\text { GSYH İçindeki } \\
\text { Oranı } \\
\%\end{array}$ \\
\hline $\mathbf{2 0 0 6}$ & 1.772 & 182.610 & 0,97 & 0,23 \\
$\mathbf{2 0 0 7}$ & 2.824 & 215.059 & 1,31 & 0,33 \\
$\mathbf{2 0 0 8}$ & 2.848 & 233.956 & 1,22 & 0,30 \\
$\mathbf{2 0 0 9}$ & $3.495,7$ & $276.088,8$ & 1,25 & 0,37 \\
$\mathbf{2 0 1 0}$ & 3.784 & $301.656,6$ & 1,25 & 0,34 \\
$\mathbf{2 0 1 1}$ & 4.888 & 335.096 & 1,46 & 0,38 \\
$\mathbf{2 0 1 2}$ & 5.277 & $384.326,6$ & 1,37 & 0,37 \\
$\mathbf{2 0 1 3}$ & 6.835 & 396.705 & 1,54 & 0,44 \\
$\mathbf{2 0 1 4}$ & 8.239 & $480.047,8$ & 1,72 & 0,47 \\
$\mathbf{2 0 1 5}$ & 8.629 & $520.445,7$ & 1,66 & 0,44 \\
$\mathbf{2 0 1 6}$ & $10.569,6$ & $633.511,6$ & 1,67 & 0,41 \\
\hline
\end{tabular}

Kaynak: 2016 Yılı Adalet Bakanlığı Faaliyet Raporu, http://www.adalet.gov.tr, s.53. 
Tablo 1'e göre, 2006-2016 dönemi değerlendirildiğinde, merkezi yönetim bütçe ödeneklerinin artmasına paralel olarak Bakanlığın ödeneklerinde de artış görülmektedir. Buna göre, 2006 yılında Adalet Bakanlığı'nın ödeneklerinin 2016 yılına gelindiğinde yaklaşık olarak altı katına ulaştığı görülmektedir Adalet Bakanlığı ödeneklerinin miktar bakımından artmış olması, GSYH'ya oranı açısından bakıldığında aynı seviyede arttığını göstermemektedir. Dolayısıyla milli gelirdeki artışlar paralelinde Adalet Bakanlığı faaliyetleri dikkate alındığında, Bakanlık ödeneklerinin milli gelire oranla düşük seviyede kaldığı söylenebilir. Nitekim 2016 yılı Bakanlığın ödenek miktarına bakıldığında bir önceki yıla göre ciddi bir artış görünse bile, milli gelire oran yönünden bakıldığında bir önceki yıla göre azaldığı görülmektedir.

Grafik 1: 2006-2016 Yılları Arası Adalet Bakanlığı Ödeneklerinin, Merkezi Yönetim Bütçesi Iç̧indeki Payı

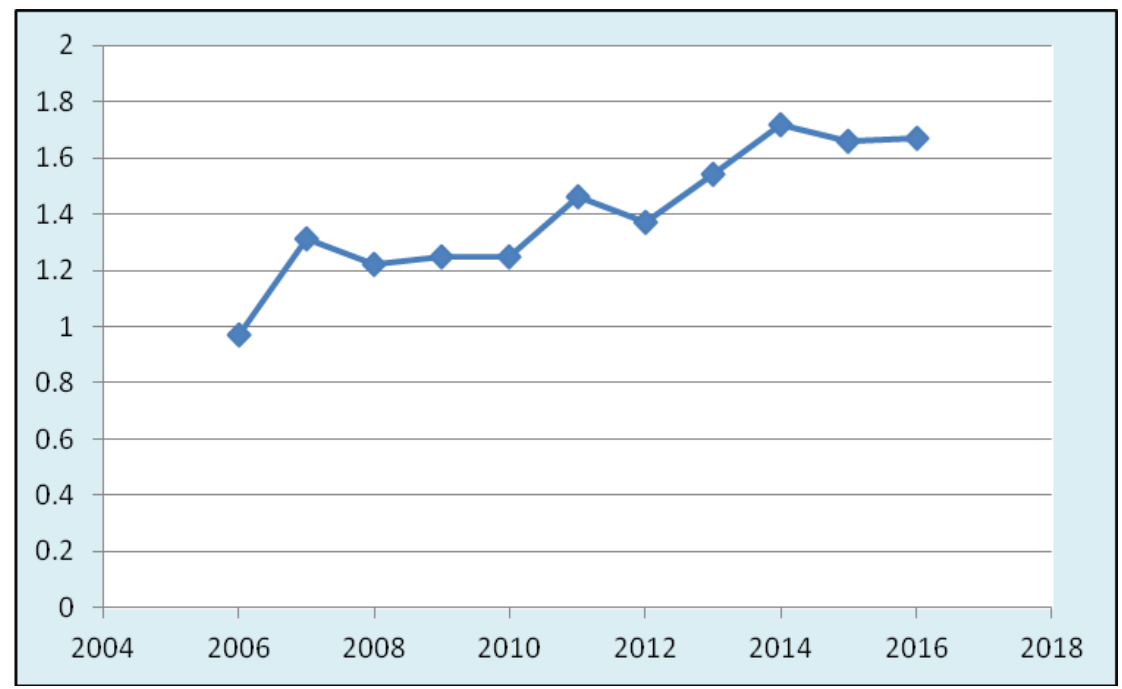

Kaynak: 2016 Yılı Adalet Bakanlığı Faaliyet Raporunda yer alan verilerden tarafımızca düzenlenmiştir.

Grafik 1 incelendiğinde, bakanlık ödeneklerinin merkezi yönetim bütçesi 2006 yılında \%0.97 olan payının 2016'da \%1.67'ye çıktığı görülmektedir.

Adalet Bakanlığı ile tüm genel bütçeli kuruluşlar ödeneklerini ayrıntılı olarak ekonomik sınıflandırma üzerinden göstermektedirler. Ekonomik sınıflandırma içinde yer alan dokuz kalem itibariyle kurumların merkezi yönetim bütçesinden aldıkları toplam ödenek ayrıntılı bir şekilde ortaya çıkmaktadır. Ekonomik sınıflandırmanın kurumlara getirdiği en önemli avantaj, her bir kurumun yaptığı harcamaların ayrıntılı analize tabi tutularak harcamalar itibariyle milli gelir üzerindeki etkilerinin ve bütçe politikalarının sağlıklı bir şekilde işlemesine imkân tanımasıdır.

Nitekim Bakanlığın ekonomik sınıflandırmaya göre toplam ödeneklerinin ve harcamalarının 2010-2016 dönemine ilişkin gelişimine Tablo 2 ve Tablo 3'de yer verilmiştir. 
Eskişehir Osmangazi Üniversitesi ïBß Dergisi

Tablo 2: 2010-2016 Yılları Arasında Ekonomik Sınıflandırmaya Göre Adalet Bakanlığı Ödenekleri (Milyon TL)

\begin{tabular}{|c|c|c|c|c|c|c|c|c|}
\hline \multirow{2}{*}{ Kod } & & \multicolumn{7}{|c|}{ Toplam Ödenek } \\
\hline & & 2010 & 2011 & 2012 & 2013 & 2014 & 2015 & 2016 \\
\hline 01 & $\begin{array}{l}\text { Personel Gider- } \\
\text { leri }\end{array}$ & 1.813 & 2.757 & 3.544 & $3.964,8$ & 4.561 & 3.869 & 6.274 \\
\hline 02 & $\begin{array}{l}\text { Sos. Güv. Kur. } \\
\text { Dev. Primi Gid. }\end{array}$ & 355 & 442 & 522 & 594 & 693 & 743 & 933 \\
\hline 03 & $\begin{array}{l}\text { Mal ve Hiz. } \\
\text { Alımları }\end{array}$ & 687,9 & 840 & 1.097 & 1.334 & 1.469 & $1.655,6$ & $1.867,8$ \\
\hline 05 & Cari Transferler & 164,8 & 328 & 141 & 267 & 604 & 635 & 333 \\
\hline 06 & $\begin{array}{l}\text { Sermaye Gider- } \\
\text { leri }\end{array}$ & 66 & 191 & 176 & 384,9 & 491 & 665,8 & 748 \\
\hline 07 & $\begin{array}{l}\text { Sermaye Trans- } \\
\text { ferleri }\end{array}$ & 354 & 505 & 513 & 681,5 & 725 & 898 & $1.075,8$ \\
\hline Gene & oplam & $3.440,8$ & 5.089 & 5.994 & 7.226 & $8.543,7$ & 8.467 & 11.233 \\
\hline
\end{tabular}

Kaynak: Adalet Bakanlığı Faaliyet Raporları, http://www.adalet.gov.tr, (Erişim:15.05.2017).

Tablo 3: 2010-2016 Yılları Arasında Ekonomik Sınıflandırmaya Göre Adalet Bakanlığı Harcamaları (Milyon TL)

\begin{tabular}{|c|c|c|c|c|c|c|c|c|}
\hline \multirow{2}{*}{ Kod } & & \multicolumn{7}{|c|}{ Toplam Harcama } \\
\hline & & 2010 & 2011 & 2012 & 2013 & 2014 & 2015 & 2016 \\
\hline 01 & $\begin{array}{l}\text { Personel } \\
\text { Giderleri }\end{array}$ & $2.301,7$ & 2.760 & 3.541 & $3.960,9$ & 4.554 & 5.265 & 6.253 \\
\hline 02 & $\begin{array}{l}\text { Sos. Güv. } \\
\text { Kur. Dev. } \\
\text { Primi Gid. }\end{array}$ & 378 & 442 & 521 & 591 & 691 & 771,5 & 929 \\
\hline 03 & $\begin{array}{l}\text { Mal ve Hiz. } \\
\text { Alımları }\end{array}$ & 684 & 852,6 & $1.097,7$ & 1.316 & $1.455,7$ & 1.637 & $1.842,7$ \\
\hline 05 & $\begin{array}{l}\text { Cari Trans- } \\
\text { ferler }\end{array}$ & 162,9 & 328 & 139,7 & 256,6 & 573 & 610,6 & 327 \\
\hline 06 & $\begin{array}{l}\text { Sermaye } \\
\text { Giderleri }\end{array}$ & 44,7 & 191 & 153,9 & 342 & 466 & 664 & 726 \\
\hline 07 & $\begin{array}{l}\text { Sermaye } \\
\text { Transferleri }\end{array}$ & 354 & 505 & 513 & 681,5 & 725 & 898,5 & 1.074 \\
\hline Gene & oplam & $3.925,6$ & 5.079 & 5.967 & 7.148 & 8.465 & 9.847 & 11.152 \\
\hline
\end{tabular}

Kaynak: Adalet Bakanlığı Faaliyet Raporları, http://www.adalet.gov.tr, (Erişim:15.05.2017).

Tablo 2 ve Tablo 3'den görüldüğü gibi, Adalet Bakanlığı toplam ödenekleri 2016 yılı dikkate alındığında, mevcut kalemler içerisinde en yüksek paya sahip olan kalem personel giderleri olup, bu kalemin genel toplam içindeki payı \% 55 seviyesindedir. Diğer kalemler bakımından ise, cari transferler dışındaki kalemlerin yıllar itibariyle artış gösterdiği görülmektedir. Öte yandan, Bakanlığın harcamaları ele alındığında, yine aynı şekilde en yüksek payı personel giderlerinin aldığı, en düşük payın ise cari transferler kalemine ait olduğu görülmektedir. Buradan anlaşılması gereken, bakanlığın toplam ödeneğinin içerisinden harcamaya dönüşen kısmı dikkate alınması gerektiğidir. Ancak merkezi yönetim kapsamındaki tüm kurumların ekonomik sınıflandırmaya dahil olan tüm kalemlerini baz alarak ödeneklerini ve harcamalarını göstermesi gerekirken, faaliyet raporlarında bazı kodlara (04 Faiz Giderleri, 08 Borç Verme ve 09 Yedek Ödenek) yer verilmemiş olması, o yıllar içerisinde bu kalemlere ilişkin herhangi bir faaliyetinin olmadığını göstermektedir. 
Fonksiyonel sınıflandırma, kamu harcamalarının sınıflandırılması açısından son derece önem taşımaktadır. Bu sınıflandırma ile kamu hizmet alanlarının belirlenmesi ve detaylı bir şekilde analiz edilmesi mümkün olabilmektedir. Bu bağlamda, fonksiyonel sınıflandırma hizmetlerin sosyal fayda-maliyet kıyaslamaları yapılabilmesine imkân tanımaktadır. Fonksiyonel sınıflandırmanın net olarak tespiti, bir fonksiyona ait tüm harcamaların toplam maliyetlerinin bilinmesini gerektirmektedir.

Adalet Bakanlığı'nın 2010-2016 dönemine ilişkin fonksiyonel sınıflandırmaya göre ödenek ve harcamaları Tablo 4 ve Tablo 5 incelendiğinde, en yüksek payı kamu düzeni ve güvenlik hizmetlerinin aldığı görülmektedir. Söz konusu kalemin toplam ödenek ve harcamalara oranı ortalama \% 81 civarındadır.

Tablo 4: 2010-2016 Yılları Arasında Fonksiyonel Sınıflandırmaya Göre Adalet Bakanlığı Ödenekleri (Bin TL)

\begin{tabular}{lcccccc}
\hline Açıklama & $\mathbf{2 0 1 1}$ & $\mathbf{2 0 1 2}$ & $\mathbf{2 0 1 3}$ & $\mathbf{2 0 1 4}$ & $\mathbf{2 0 1 5}$ & $\mathbf{2 0 1 6}$ \\
\hline Genel Kamu Hizmetleri & 1.070 .012 & 876.144 & 1.370 .275 & 1.878 .539 & 2.289 .307 & 2.118 .210 \\
$\begin{array}{l}\text { Savunma Hizmetleri } \\
\text { Kamu Düzeni ve }\end{array}$ & 209 & 183 & 171 & 269 & 233 & 238 \\
Güvenlik Hizmetleri & 4.018 .833 & 5.118 .039 & 5.855 .948 & 6.664 .869 & 6.177 .919 & 9.114 .461 \\
\hline Toplam & 5.089 .054 & 5.994 .365 & 7.226 .394 & 8.543 .677 & 8.467 .459 & 11.232 .909 \\
\hline
\end{tabular}

Kaynak: Adalet Bakanlığı Faaliyet Raporları, http://www.adalet.gov.tr, (Erişim:15.05.2017).

Tablo 5: 2010-2016 Yılları Arasında Fonksiyonel Sınıflandırmaya Göre Adalet Bakanlığı Harcamaları (Bin TL)

\begin{tabular}{lcccccc}
\hline Açıklama & $\mathbf{2 0 1 1}$ & $\mathbf{2 0 1 2}$ & $\mathbf{2 0 1 3}$ & $\mathbf{2 0 1 4}$ & $\mathbf{2 0 1 5}$ & $\mathbf{2 0 1 6}$ \\
\hline Genel Kamu Hizmetleri & 1.060 .315 & 851.078 & 1.321 .440 & 1.820 .698 & 2.263 .110 & 2.087 .388 \\
$\begin{array}{l}\text { Savunma Hizmetleri } \\
\text { Kamu Düzeni ve }\end{array}$ & 189 & 174 & 169 & 267 & 229 & 230 \\
Güvenlik Hizmetleri & 4.018 .861 & 5.115 .863 & 5.826 .654 & 6.644 .471 & 7.583 .596 & 9.064 .808 \\
\hline Toplam & 5.079 .365 & 5.967 .115 & 7.148 .263 & 8.465 .434 & 9.846 .934 & 11.152 .425 \\
\hline
\end{tabular}

Kaynak: Adalet Bakanlığı Faaliyet Raporları, http://www.adalet.gov.tr, (Erişim:15.05.2017).

Kalkınma Planlarında belirtilen yatırım hedefleri bir ülkenin toplam yatırım hacmini ve sermaye birikimini doğrudan etkilemektedir. Merkezi yönetim bütçesi içindeki yatırım harcamalarının nispi payı bu hedefe ulaşmada önemli bir göstergedir. Ancak ülkemizde merkezi yönetim bütçesi içindeki yatırım ödeneklerinin nispi payı oldukça düşük kalmaktadır. Adalet Bakanlığı'nın Dokuzuncu ve Onuncu Kalkınma Plan hedefleri çerçevesinde yatırımlarının dağılımının gösterildiği Grafik 2'ye bakıldığında, 2011 yılında 172.700 Bin TL olan yatırım bütçesi, 2016 yılına gelindiğinde 1.173,9 Bin TL olarak gerçekleşmiştir. Bakanlığın toplam ödenekleri (bkz Tablo 4) içinde yatırım bütçesi payı 2011 yılında \%0.033 iken 2016 yılında ise \%0.10 ‘a yükselmiştir. 
Grafik 2: 2010-2016 Yılları Arasında Adalet Bakanlığı Yatırım Bütçesi (Bin TL)

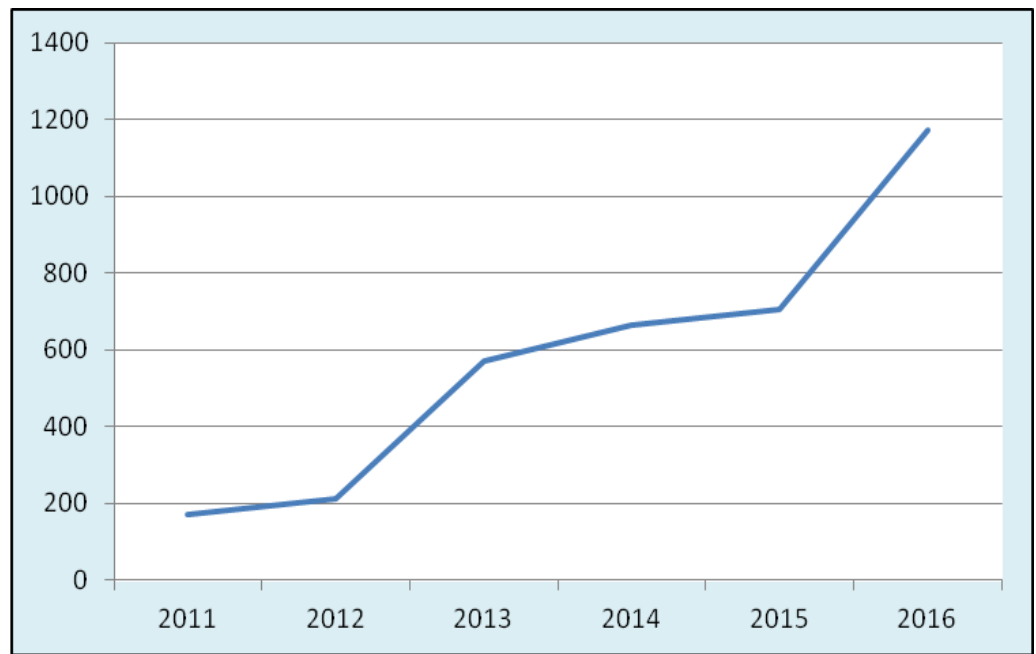

Kaynak: Adalet Bakanlığı Faaliyet Raporları yatırım bütçesi verilerinden tarafımızca düzenlenmiştir.

Grafik 2'ye göre bakanlık yatırım bütçesinin 2011 yılından 2016 yılına \% 570 dolayında artış gösterdiği görülmektedir. Günümüzde sürdürülebilir kalkınma çerçevesinde yerli ve yabancı yatırımlar, hukuk sisteminde görülen iyileşmeler doğrultusunda ülkelere yönlenmektedir. Türkiye'de adalet harcamalarında yatırım bütçesinin artması da özellikle bilgi teknolojilerinin yargılama faaliyetlerine yansıması ile pek çok olumlu sonuç doğurmaktadır. Bunların başında, yargılama sürelerinin kısalması gelmektedir. Mevcut durumda istenilen seviyelere halen ulaşılamamış olması, bu alana yönlendirilecek olan yatırım bütçelerinin daha da artması gereğini ortaya çıkarmaktadır.

\section{Sonuç}

Türkiye'de adalet hizmetleri ve bu bağlamda yapılan kamu harcamaları sosyo-ekonomik ve mali açıdan oldukça önemlidir. Ülkemiz Avrupa Birliği müktesebatına uyum çerçevesinde bu konuya ilişkin önemli hedefler belirlemiş ve uygulamalarla pekiştirmeye yönelik adımlar atmıştır. Bu konuya ilişkin Kalkınma Planlarında adalet hizmetlerinin iyileştirilmesine yönelik politika ve hedeflere yer verilmektedir. Özellikle son iki kalkınma plan hedeflerine bakıldığında, adalet ve yargı sistemimizin $A B$ normlarına uyarlanması amacıyla köklü yasal düzenlemelere yer verilmiştir. Buna göre adalet hizmetlerine yönelik Dokuzuncu Kalkınma Planı değerlendirildiğinde, adalet sisteminin iyileştirilmesi amacıyla siyasi, sosyal ve ekonomik değişiklikler karşısında günün ihtiyaçlarına cevap veremeyen temel kanunların yenilenmesi ve bu bağlamda Türk Medeni Kanunu, Türk Ceza Kanunu, Ceza Muhakemesi Kanunu, Türk Ticaret Kanunu, Türk Borçlar Kanunu gibi kanunlar yürürlüğe girdiği görülmektedir. Ayrıca bu plan döneminde adalet hizmetlerinin fiziki imkânlar yönüyle geliştirilmesi hedeflenmiş ve adalet binaları hükümet konaklarından ayrılarak e-adalet konusunda önemli mesafeler kaydedilmiştir. Ancak, hukuk kurallarının oluşturulması açısından yeni gelişmelerin yeterince takip edilememesi, yargı süreçlerinin yavaş işlemesi, fiziksel ve teknik altyapı ihtiyaçlarının yeterince karşılanamaması adalet hizmetlerinin, hizmet kalitesi yönünden etkinliğini olumsuz yönde etkilemiştir. 
Adalet hizmetleri ve harcamaları yönünden Onuncu Kalkınma Planına bakıldığında, Dokuzuncu Kalkınma Planı döneminde çıkartılan temel kanunların Türk-AB Hukuku arasındaki uyumun sağlanması açısından önemli bir rol oynadığı görülmüştür. Ayrıca tüm disiplin cezaları yargı denetimi kapsamına alınmış ve idari yargının iş yükünü azaltmak için Kamu Denetçiliği Kurumu kurulmuştur. Bu plan döneminde, adalet binalarının sayısı arttırılarak, Ulusal Yargı Ağı Projesi (UYAP)'ın altyapısı tamamlanmıştır. Bütün bu çalışmalar adalet hizmetlerine dönük harcamaların devlet bütçesinden aldığı payların nispi olarak artmasını gerektirmiştir. Nitekim Türkiye'de adalete erişim, uzun yargılama ve tutukluluk süreleri, adli yardımların yetersizliği, cezaevi koşullarının kötülüğü gibi konular adalet hizmetlerinin geliştirilmesi gerektiği yönünde ele alınmaktadır.

Türkiye'de adalet hizmetlerine yönelik yapılan harcamalara rağmen adalet hizmetlerinden beklenen etkinliğe ulaşabilmek yönünden bütçeden daha fazla nispi anlamda pay alması gerektiği ortadadır. Çünkü adalet harcamaları günümüzde Merkezi Yönetim bütçesi içinde halen çok düşük oranlarda gerçekleşmektedir. Adalet harcamalarının bütçedeki nispi payının artırılmasına yönelik yapılacak iyileşmeler, adalet hizmetlerinin kalitesini ve adalet hizmetlerinin sosyo-ekonomik ve mali yönden ortaya çıkabilecek olumlu etkileri de beraberinde getirecektir. Buna göre, ekonomik hedefler yönünden öngörülebilirliğin artması, toplam yatırım hacminin artırılması, vergi kayıp ve kaçakları ile etkin mücadele edilerek kayıt dışı ekonominin boyutlarının düşürülmesi ve toplumun adalet sisteminden beklentilerinin artırılarak bu konuda güven ortamının oluşturacak politika ve uygulamalara yer verilmesi gerekmektedir. 


\section{Eskişehir Osmangazi Üniversitesi IïB Dergisi}

\section{Kaynaklar}

Aktan, C. C. (2013), "Piyasa Başarısızlığının Anatomisi ve Kamu Ekonomisi Rasyoneli”. Kamu Ekonomisi-ı. Ed: Coşkun Can Aktan ve Dilek Dileyici. Eskişehir: Anadolu Üniversitesi Yayınları. 2. Baskı.

Bulutoğlu, K. (2008), Kamu Ekonomisine Giriş: Demokraside Devletin Ekonomik Bir Kuramı. Maliye ve Hukuk Yayınları: 7.Baskı. Ankara.

Bulutoğlu, K. (2004), Kamu Bütçesi Kamu Harcamaları Kamu Borçları, İstanbul: Batı Türkeli Yayıncılık.

CEPEJ (2006), European Judicial System. Edition 2008 (data 2006), Efficiency and Quality of Justice, Belgium.

CEPEJ (2014), European Judicial System. Edition 2008 (data 2006), Efficiency and Quality of Justice, Belgium.

Deyneli, F. (2011), "Türkiye'de Adalet Harcamalarının Ekonomik Büyüme Üzerindeki Etkileri”, Sosyoekonomi, C.1, S:1: 7-22.

Eker, A. (2010), Kamu Maliyesi, İzmir: Birleşik Matbaası.

Gözler, K. (2008), “Tabiî Hukuk ve Hukukî Pozitivizme Göre Adalet Kavramı”. Muhafazakâr Düşünce, C.4, S. 15: 77-90.

Güriz, A. (2001), Adalet kavramı, Ankara: Türkiye Felfese Kurumu Yayınları, 2. Baskı.

Hay, J. R., A. Shleifer, R. W. Vishny (1996), “Toward A Theory of Legal Reform”. European Economic Review, C.40, S.1:

559-567.

Klerman, D. M. (2007), Legal Infrastructure, Judicial Independence and Economic Development, http://www.mcgeorge.edu/Documents/Conferences/JUDIND_KLERMAN_MASTER.pdf, pp. 427-434, (Erişim: 10.05.2017).

Kirmanoğlu, H. (2014), Kamu Ekonomisi Analizi. Gözden Geçirilmiş 5. Baskı, İstanbul: Beta Yayınları.

Messick, R. E. (1999), "Judicial Reform and Economic Development: A Survey of the Issues”, The World Bank Research Observe, C.14, S.1: 117-36.

Methibay, Y. (2014), Harcama Hukuku, Ankara: Orion Kitabevi.

Sili, A. (2014), "Adalet, Hukuk ve Şiddet Arasında Yasalar". Hukuka Felsefi ve Sosyolojik Bakışlar - VI. Haz: Hayrettin ÖKÇE, Gülriz UYGUR ve Saim ÜYE. Sempozyum İstanbul Barosu-HFSA Bildiriler. 26.Kitap. İstanbul Barosu Yayınları: 375381.

Pinheiro, A. (1996), Judicial System Performance and Economic Development. www.nuca.ie.ufrj.br/livro/estudos/pinheiro2.doc: 1-42. (Erişim: 18.05.2017).

T.C. Adalet Bakanlığı Stratejik Planı (2015-2019), http://www.sgb.adalet.gov.tr, (Erişim: 15.05.2017).

T.C. Adalet Bakanlığı Faaliyet Raporu (2016), http://www.adalet.gov.tr, (Erişim:15.5.2017).

T.C. Kalkınma Bakanlığı, Dokuzuncu Kalkınma Planı (2007-2013), http://www.kalkinma.gov.tr, (Erişim: 19.05.2017).

T.C. Kalkınma Bakanlığı, Onuncu Kalkınma Planı (2014-2018), http://www.kalkinma.gov.tr, (Erişim: 19.05.2017).

Tüğen, K. (2016), Devlet Bütçesi, İzmir: Başsaray Matbası, Onbeşinci Baskı. 